\title{
Post-transcriptional regulation of microRNA expression
}

\author{
GREGOR OBERNOSTERER, ${ }^{1,3}$ PHILIPP J.F. LEUSCHNER, ${ }^{1,3}$ MATTIAS ALENIUS, ${ }^{2,3}$ and JAVIER MARTINEZ ${ }^{1}$ \\ ${ }^{1}$ Institute of Molecular Biotechnology of the Austrian Academy of Sciences (IMBA), A-1030 Vienna, Austria \\ ${ }^{2}$ Institute of Molecular Pathology (IMP), A-1030 Vienna, Austria
}

\begin{abstract}
microRNAs (miRNAs) are endogenous, noncoding $\sim 22$-nucleotide RNA molecules that have recently emerged as fundamental, post-transcriptional regulators of cognate target gene expression. Many mammalian miRNAs are expressed in a tissue-specific manner, a phenomenon that has so far been attributed to transcriptional regulation. We here show by Northern blots and in situ hybridization experiments that the expression of mammalian miRNAs can be regulated at the post-transcriptional level. In particular, miR-138 is spatially restricted to distinct cell types, while its precursor, pre-miR-138-2, is ubiquitously expressed throughout all tissues analyzed. Furthermore, pre-miR-138-2 is exported from the nucleus to the cytoplasm, suggesting that cleavage of this pre-miRNA by Dicer is restricted to certain tissues and cell types. Thus, differential processing of pre-miRNAs might be an alternative mechanism to control miRNA function.
\end{abstract}

Keywords: microRNAs; post-transcriptional regulation; Dicer; tissue-specific expression

\section{INTRODUCTION}

miRNAs are a family of small $(\sim 22$ nucleotides [nt]), endogenous, noncoding RNAs that, by binding complementary sequences in the $3^{\prime}$ untranslated region (3' UTR) of messenger RNAs (mRNAs), either mediate translational repression or direct mRNA cleavage (Pillai 2005). miRNAs are transcribed as mono- or polycistronic, long, primary precursor transcripts (pri-miRNAs) that are cleaved into $\sim 70$-nt precursor hairpins, known as pre-miRNAs, by the nuclear RNase III-like enzyme Drosha (Lee et al. 2003). Subsequently, pre-miRNA hairpins are exported to the cytoplasm by Exportin-5 (Yi et al. 2003; Bohnsack et al. 2004; Lund et al. 2004), where they are processed by a second RNase III-like enzyme, termed Dicer, into 22-nt duplexes (Bernstein et al. 2001; Hutvágner et al. 2001; Ketting et al. 2001; Knight \& Bass 2001), followed by the asymmetric assembly of one of the two strands into a functional miRNP or miRISC (Khvorova et al. 2003; Schwarz et al. 2003).

More than 800 miRNAs have so far been experimentally discovered in mammals (Lagos-Quintana et al. 2001, 2002;

\footnotetext{
${ }^{3}$ These authors contributed equally to this work.

Reprint requests to: Javier Martinez, Institute of Molecular Biotechnology of the Austrian Academy of Sciences, Dr.-Bohr-Gasse 3-5, A-1030 Vienna, Austria; e-mail: javier.martinez@imba.oeaw.ac.at; fax: +43 (1) 79044-110.

Article published online ahead of print. Article and publication date are at http://www.rnajournal.org/cgi/doi/10.1261/rna.2322506.
}

Bentwich et al. 2005) and some of them are highly conserved between invertebrates and vertebrates (Bartel 2004). However, through the development of increasingly sophisticated algorithms based on machine learning techniques, the number of predicted miRNAs currently amounts to a few thousand (Lim et al. 2003; Bentwich et al. 2005; Berezikov et al. 2005). Many mammalian miRNAs are tissue- and/or developmental stage-specifically expressed. Several microarray profiling studies have shown that the expression pattern of a large number of miRNAs can be attributed to regulatory sequences present in their promoters (Babak et al. 2004; Barad et al. 2004; Calin et al. 2004; Liu et al. 2004; Miska et al. 2004; Sempere et al. 2004). Furthermore, host genes harboring miRNA sequences in their intronic sites impose their pattern of expression to the respective miRNAs (Bartel 2004; Rodriguez et al. 2004).

The current view suggests that miRNA expression is mainly controlled at the transcriptional level. For example, the transcription factors MyoD, Mef2, and SRF determine the heart-specific expression of miR-1 (Zhao et al. 2005). A recent study by O'Donnell and colleagues (O'Donnell et al. 2005) shows that the proto-oncogene c-Myc activates the expression of the $m i R-17-92$ cluster. However, like other RNAs, miRNA expression could potentially be controlled at the post-transcriptional level (Pillai 2005). It has been shown in Caenorhabditis elegans that $m i R-38$ is regulated in a temporal manner by differential maturation of premiR-38 during development (Ambros et al. 2003). We here 
provide conclusive evidence that also mammalian miRNA expression can be regulated at the level of miRNA processing.

\section{RESULTS AND DISCUSSION}

As a first step in validating targets of a set of brain-specific miRNAs, we isolated total RNA from brain and other mouse tissues, as well as from HeLa cells, and performed Northern blots with miRNA-specific probes. As expected for $m i R-138$, the mature $\sim 23$-nt miRNA was detectable only in brain tissue (Fig. 1A). In particular, we found that miR-138 was expressed in the cerebrum, the cerebellum, and the midbrain of adult mice as well as in the murine neuroblastoma cell line N2A (Fig. 1B). Strikingly, its putative $\sim 69$-nt precursor was present in all tissues and cells analyzed (Fig. 1A, left panel; 1B), suggesting that the ubiquitously expressed precursor is processed into the mature miRNA in a tissue-specific manner.

Two putative precursors were recently predicted for miR-138, termed "pre-miR-138-1" and "pre-miR-138-2," which are encoded on different chromosomal loci and are $62 \mathrm{nt}$ and $69 \mathrm{nt}$ in size, respectively (Lagos-Quintana et al. 2002; Griffiths-Jones 2004; Weber 2005). Multiple sequence alignments (Schwartz et al. 2000) of the two chromosomal regions showed high conservation of the mature miRNA among different vertebrate species, whereas only the locus of miR-138-2 showed an overall conservation pattern in the flanking sequences (Supplemental Material).

To check that (1) the $\sim 69$-nt band is indeed a precursor miRNA and, if so, (2) which of the two precursors is ubiquitously expressed, we performed Northern blots with total RNA isolated from HeLa cells and probed against the mature sequence as well as sequences specific for the loop regions of the two different precursors. Interestingly, the probe against the mature miR-138 showed a single band at $69 \mathrm{nt}$, which was also revealed by a probe against the loop region of pre-miR-138-2 (Fig. 1C). Mismatches in the probes against the sequences of the mature miR-138 and of pre-miR-138-2 abolished detection of the 69-nt band (Supplemental Material), indicating that the ubiquitously expressed $\sim 69$-nt band shown in Figure $1, A$ and $B$, is indeed a precursor of miR-138, and that the mature miR-138 derives from pre-miR-138-2. In agreement with this, we were not able to detect a 62-nt band that would correspond to pre-miR-138-1 (Fig. 1C) either with a mature probe or with a probe against the loop region of pre-miR-138-1.

To further investigate the overall distribution of miR-138 and its precursor, we performed in situ hybridizations with 3' DIG-labeled LNA oligonucleotide probes on cryo-sections of E17 mouse embryos (Fig. 2A) and adult brain (Fig. 2B). We observed a strong staining in the central nervous system (CNS) for mature miR-138 (Fig. 2A, left panel). In particular, miR-138 was primarily localized to most neurons in the hippocampus and to specific regions of the neocortex, but also to the cerebellum (Fig. 2A, left panel; 2B, upper panel). This clearly demonstrates that expression of miR-138 is not uniform throughout the brain but restricted to distinct neuronal populations. Surprisingly, $m i R-138$ was also expressed in fetal liver (Fig. 2A, left panel; 2C) but not in adult liver (Fig. $2 \mathrm{C})$, indicating that the expression of miR-138 is also developmentally regulated. To confirm the ubiquitous expression observed for pre-miR-138-2 in Northern blots performed with total 
A
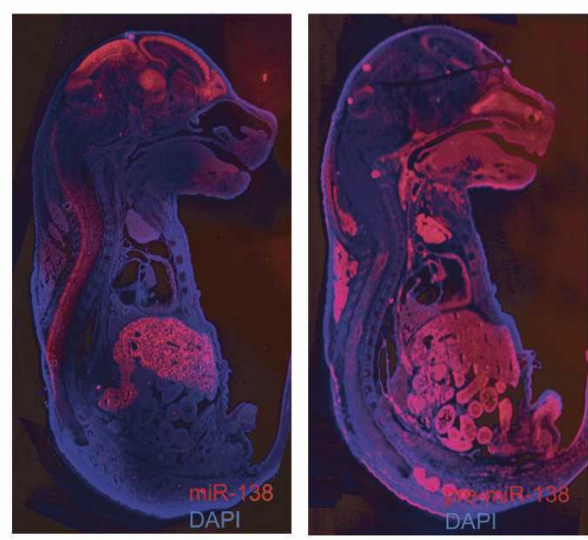

C
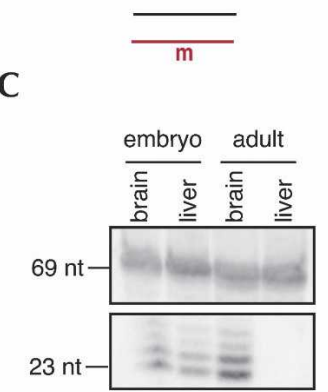

B
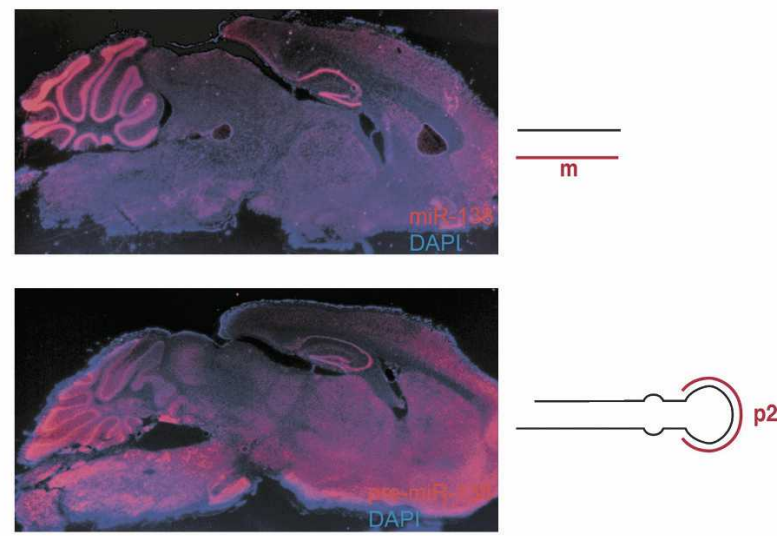

D

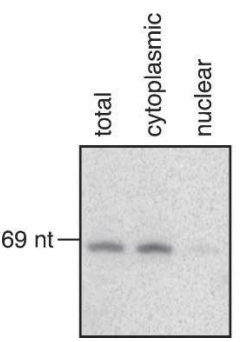

FIGURE 2. (A) In situ hybridization experiment on cryo-sections of E17 mouse embryos using LNA-modified probes that recognize mature miR138 (left panel) or pre-miR-138-2 (right panel). The probe against mature miR-138 shows a strong expression in neuronal tissues (brain, CNS) and also in fetal liver, while the probe hybridizing to pre-miR-138-2 gives a strong signal in almost all tissues of the embryo. The seemingly low level of pre-miR-138-2 in brain can be explained by a low cellular density of the brain region as well as to a short exposure time used to prevent overexposure of tissues with higher cellular density. Magnifications of the fetal brain region can be seen in the Supplemental Material, where exposure time has been optimized to visualize expression of both mature miR-138 and pre-miR-138-2. (B) In situ hybridization experiments on cryo-sections of adult mouse brain using LNA-modified oligonucleotide probes that recognize mature miR-138 (upper panel) or pre-miR-138-2 (lower panel). miR-138 is primarily located to specific regions of the neocortex, most neurons in the hippocampus, and granule and purkinje cells of the cerebellum, while pre-miR-138-2 is essentially uniformly distributed. Magnifications of the cerebellum can be seen in the Supplemental Material. (C) Northern blot analysis of miR-138 expression in fetal and adult brain and liver. One hundred micrograms of total RNA prepared from the indicated tissues were blotted and probed for miR-138. In the mouse embryo, miR-138 is expressed in both brain and liver, which is in agreement with the findings in the in situ hybridization experiments. In the adult, miR-138 is restricted to brain. $(D)$ Northern blot of total HeLa RNA and cytoplasmic and nuclear RNA fractions from HeLa cells probed against pre-miR-138-2. The band at 69 nt corresponds to pre-miR-1382 that is mainly found in the cytoplasmic fraction, indicating nuclear export of the precursor.

RNA from adult tissues, we prepared a probe recognizing the loop region of the pre-miR-138-2 hairpin. Like Northern blots, in situ hybridizations showed a broad expression of pre-miR-138-2 in most organs of the embryo (Fig. 2A, right panel) as well as in adult brain (Fig. 2B, lower panel). To summarize, these data (Northern blots and in situ hybridizations) suggest that pre-miR-138-2 processing is both temporally and spatially regulated.

How is this differential processing achieved? A tempting hypothesis is that the export of pre-miR-138-2 is impaired in all tissues except brain, thus preventing cleavage by Dicer in the cytoplasm. To evaluate this possibility, we isolated cytoplasmic and nuclear RNA from HeLa cells, where premiR-138-2 is not processed, and examined its subcellular distribution. Northern blot analysis showed that the precursor is effectively exported to the cytoplasm (Fig. 2D), indicating that cleavage by Dicer could be the regulated step.
We envision that tissue-specific expression could be achieved either by an activator present in tissues that express $m i R-138$ or, alternatively, by an inhibitor acting on tissues that lack expression of $m i R-138$. We were able to show that recombinant Dicer enzyme is able to convert pre-miR-138-2 into mature miR-138, a result that rules out the activator model (Fig. 3A). Thus, we favor the presence of an inhibitory factor, which binds pre-miR-138-2 and prevents its conversion into a mature miR-138 by Dicer in all tissues not expressing miR-138. This hypothesis is fostered by in vitro experiments, where the addition of increasing amounts of HeLa cytoplasmic extracts readily abolished processing of pre-miR-138-2 by recombinant Dicer (Fig. 3B). Importantly, processing of pre-miR-19a, a miRNA that is normally expressed in HeLa cells (LagosQuintana et al. 2001), was not abolished by titrating increasing amounts of HeLa cytoplasmic extracts (Fig. 
A

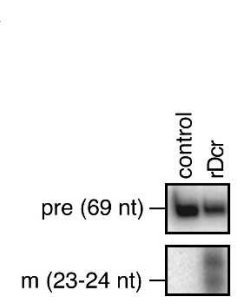

D

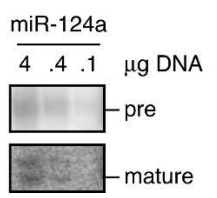

B

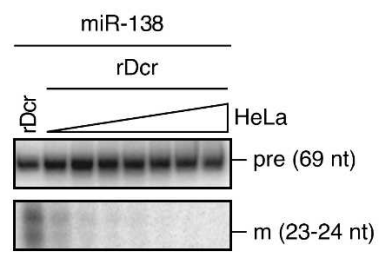

$\mathbf{E}$

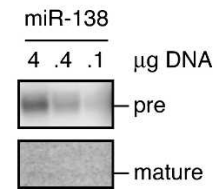

C

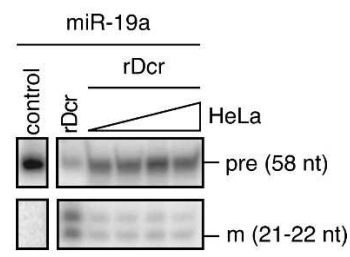

FIGURE 3. (A) Processing reaction of pre-miR-138-2 into mature miR-138 by recombinant Dicer (rDcr) resolved on a 15\% denaturing PAGE. (B) As in A. The addition of increasing amounts of HeLa cytoplasmic extract effectively abolishes the processing of pre-miR-138-2. The band corresponding to the respective pre-miRNA is indicated by "pre," whereas the band representing the mature miRNA is designated by " $\mathrm{m}$." $(C)$ Processing of pre-miR-19a into mature miR-19a is not abolished by addition of increasing amounts of HeLa cytoplasmic extract. The efficiency of processing is reduced by the addition of HeLa cytoplasmic extracts; however, the level of processing does not decrease with higher amounts of HeLa cytoplasmic extracts. $(D)$ HeLa cells were transfected with the indicated amounts of a plasmid encoding the sequence of pre-miR-124a. The conversion of pre-miR-124a into mature miR-124a was monitored by Northern blotting. (E) HeLa cells were transfected with the indicated amounts of a plasmid encoding the sequence of pre-miR-138-2. In contrast to pre-miR-124a, HeLa cells failed to process pre-miR-138-2 into mature miR-138. Note that pre-miR-138-2 is more abundant than pre-miR-124a.

3C). We further analyzed pre-miRNA processing in living cells. For this purpose, we transfected HeLa cells transiently with plasmids encoding either pre-miR-124a or pre-miR138-2 under the control of the $\mathrm{H} 1$ promoter. Northern blots showed that pre-miR-124a was converted into the mature miR-124a, whereas pre-miR-138-2 was not processed (Fig. 3D,E). This suggests that HeLa cells, and possibly all other tissues and cells that do not express miR-138, may contain a factor that specifically recognizes pre-miR-138-2 and inhibits its processing by Dicer. Thus, tissues and cells that do express miR-138 may lack this factor or may render it inactive, allowing Dicer cleavage to occur (Fig. 4).

In this report we demonstrate that differential processing of precursor miRNAs into mature miRNAs leads to tissueand developmental-specific miRNA expression in mammals. The presence of an unprocessed miRNA precursor in most tissues of the organism is intriguing. It could be envisioned that the unprocessed precursor might play a different role in the cell, irrespective of the function of the mature miRNA. This novel mechanism could be a more general feature for the regulation of miRNA expression. Obviously, we are left with the question of why cells employ such a complex and energy wasteful method of restricting the function of one particular miRNA to certain cellular populations. Clearly, such regulation allows higher expression stringency, but also an opportunity for quick regulation. The precursor form of the functional miRNA is already expressed, and the cells can quickly produce the mature miRNA by modifying the regulator. This could be very important for fast responses like coupling neuronal processes in time, like LTP gene expression.

\section{MATERIALS AND METHODS}

\section{Isolation of total RNA from cells, mouse tissues, and Northern blotting}

Isolation of total RNA from cultured cells or tissues and subsequent Northern blotting was performed as previously described (Lagos-Quintana et al. 2001). Twenty micrograms of total RNA were separated in a $15 \%$ polyacrylamide gel $(20 \times 25 \mathrm{~cm})$ containing $8 \mathrm{M}$ urea (SEQUAGEL, National Diagnostics), transferred to a Hybond-N+ membrane (Amersham Biosciences), fixed by ultraviolet cross-linking $(2 \times$ auto cross-link on a Stratalink 2400 [Stratagene]), and subsequently baked for $1 \mathrm{~h}$ at $80^{\circ} \mathrm{C}$. Membranes were probed with $10 \mathrm{pmol}$ of $5^{\prime}{ }^{32} \mathrm{P}$-labeled (T4 polynucleotide kinase [New England Biolabs]) DNA/LNA (locked nucleic acid) modified oligonucleotides (Proligo), complementary to the mature and precursor miRNAs. We used DNA/ LNA probes, where every third position was substituted by a LNA nucleotide, in order to obtain an improved miRNA detection (Valoczi et al. 2004). LNA nucleotides are indicated by " ${ }^{\text {X." }}$ The sequences for the probes were as follows: miR-138, $5^{\prime}$ $\mathrm{C}^{\star} \mathrm{GGC}^{\star} \mathrm{CTG}^{\star} \mathrm{ATT}^{\star} \mathrm{CAC}^{\star} \mathrm{AAC} \mathrm{ACC}^{\star} \mathrm{AGC}^{\star} \mathrm{T}-3^{\prime}$. To differentiate between miRNA precursors and mature miRNAs, the following probes against the loop regions of the two different hairpins were designed and labeled: pre-miR-138-1, $\mathrm{C}^{\star} \mathrm{GTT}^{\star} \mathrm{CTC}^{\star} \mathrm{TGA}^{\star} \mathrm{TTG}^{\star}$ $\mathrm{GCA}^{\star} \mathrm{A}-3^{\prime}$; pre-miR-138-2, $5^{\prime}-\mathrm{G}^{\star} \mathrm{GTA}^{\star} \mathrm{AGA}^{\star} \mathrm{GGA}^{\star} \mathrm{TGC}^{\star} \mathrm{GCT}^{\star} \mathrm{G}$ $\mathrm{CT}^{\star} \mathrm{CGT}-3^{\prime}$. As a control for specificity of the probes, we used mismatch probes against pre-miR-138-2 and miR-138: mismatchloop, 5' -TAAGAGGATGCGCTGCTAAAAAACCTGATTCACAA CACCA-3', and mismatch-mature, 5' -CGGCCTGATTAAAAAA ACCAGCT- $3^{\prime}$.

Prehybridization of membranes was carried out in a buffer containing $5 \times$ SSC, $20 \mathrm{mM} \mathrm{Na}_{2} \mathrm{HPO}_{4}(\mathrm{pH} 7.2), 7 \%$ SDS, $1 \times$ Denhardt's solution, and $0.1 \mathrm{mg} / \mathrm{mL}$ sonicated salmon sperm DNA (Stratagene). Hybridizations were carried out in the same solution at $80^{\circ} \mathrm{C} .5^{\prime}{ }^{32} \mathrm{P}$-labeled probes were heated for $1 \mathrm{~min}$ at $95^{\circ} \mathrm{C}$ before addition to the hybridization solution. After hybridization, the membranes were washed twice in $5 \times$ SSC, $5 \%$ SDS and once in $1 \times \mathrm{SSC}, 1 \% \mathrm{SDS}$ at $70^{\circ} \mathrm{C}$ for $1-2 \mathrm{~min}$ each. Northern blots were then analyzed by PhosphorImaging (Storm 860, Molecular Dynamics). 


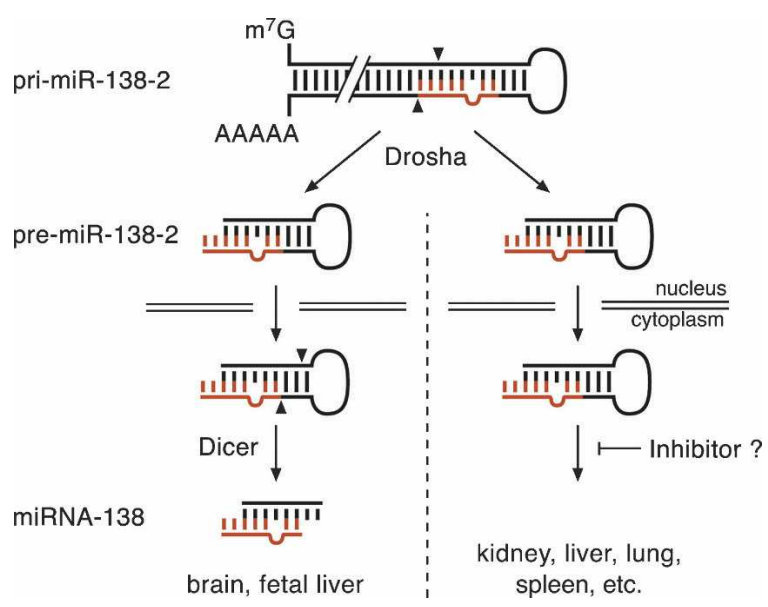

FIGURE 4. Model depicting how differential processing of an otherwise ubiquitously expressed pre-miRNA mediates tissue- and/or developmental stage-specific expression of the mature miRNA. In both tissues, expressing or not expressing the mature miR-138, its gene is transcribed into pri-miR-138-2, which is cleaved in the nucleus by Drosha into pre-miR-138-2 and then exported to the cytoplasm. Here, the presence or the absence of an inhibitory factor determines whether pre-miR-138-2 becomes processed or not, thus leading to differential expression of mature miR-138.

\section{Cell culture}

HeLa human cervix-carcinoma cells as well as N2A murine neuroblastoma cells were grown in Dulbecco's modified Eagle's medium (DMEM) (Invitrogen) supplemented with 10\% fetal calf serum (FCS) (Invitrogen), $100 \mathrm{u} / \mathrm{mL}$ penicillin (Sigma-Aldrich), $100 \mu \mathrm{g} / \mathrm{mL}$ penicillin/streptomycin (Sigma-Aldrich), and $20 \mathrm{mM}$ HEPES ( $\mathrm{pH} \mathrm{7.3)}$ at $37^{\circ} \mathrm{C}$ in an atmosphere containing $5 \% \mathrm{CO}_{2}$ in $15-\mathrm{cm}$ dishes up to $90 \%-95 \%$ confluency.

HeLa cells were transfected with the indicated amounts of pSUPER.neo+GFP plasmid (Oligoengine), where the sequences of pre-miR-124a or pre-miR-138-2 were previously inserted between the BglII and the HindIII restriction sites. For pre-miR-124a, we used 124a-fwd, 5'-GATCCCCGTGTTCACAGCGGACCTTGATT TAAATGTCCATACAATTAAGGCACGCGGTGAATGCCATTTT TA-3' ${ }^{\prime}$, and 124a-rev, 5' -AGCTTAAAAATGGCATTCACCGCGT GCCTTAATTGTATGGACATTTAAATCAAGGTCCGCTGTGAA CACGGG-3'. For pre-miR-138-2, we used 138-2-fwd, 5'-GATCC CCAGCTGGTGTTGTGAATCAGGCCGACGAGCAGCGCATCC TCTTACCCGGCTATTTCACGACACCAGGGTTTTTA-3', and 138-2-rev, 5' -AGCTTAAAAACCCTGGTGTCGTGAAATAGCCG GGTAAGAGGATGCGCTGCTCGTCGGCCTGATTCACAACAC CAGCTGGG-3'. Transfections were perfomed in 6-well plates (Nunc) using the Lipofectamine 2000 reagent (Invitrogen) with concentrations according to the product manual. Total RNA was isolated $6 \mathrm{~h}$ after the start of transfection as described above.

\section{Preparation of cellular extracts}

HeLa or N2A cells were briefly washed with $1 \times$ PBS and harvested in $1 \mathrm{~mL}$ of a buffer containing $100 \mathrm{mM} \mathrm{KCl}, 5 \mathrm{mM} \mathrm{MgCl}_{2}, 10 \%$ glycerol, $30 \mathrm{mM}$ HEPES (pH 7.4), $0.1 \mathrm{mM}$ AEBSF, and $0.5 \mathrm{mM}$ DTT by scraping with a rubber policeman. Cells were effectively lysed by sonication. The remaining cell debris was removed by centrifugation.

Nuclear and cytoplasmic extracts were prepared as previously described (Lehnertz et al. 2003). Briefly, to prepare cytoplasmic extracts, cells were harvested by trypsinization, washed, and pelleted by centrifugation. The pellet was resuspended in $1 \times$ PBS and pelleted again by spinning. PBS was removed, and the cell pellet was resuspended in cold buffer A (10 mM HEPES at $\mathrm{pH} 7.9$, $10 \mathrm{mM} \mathrm{KCl}, 0.1 \mathrm{mM}$ EDTA, $0.1 \mathrm{mM}$ EGTA, $1 \mathrm{mM}$ DTT, $0.5 \mathrm{mM}$ PMSF) by gentle pipetting. After swelling, a $10 \%$ solution of Nonidet NP-40 (Fluka) was added and the tube was vigorously vortexed. The homogenate was centrifuged, and the supernatant containing the cytoplasm and the cytoplasmic RNA was transferred to a fresh tube and subsequently used for RNA extraction and Northern blot analysis. Nuclei were prepared by centrifugation of the cells through a cushion of nuclear isolation buffer (20\% [v/v] Ficoll-Paque Pharmacia, $80 \mathrm{mM}$ Tris/HCl at $\mathrm{pH} 7.4$, $8 \mathrm{mM} \mathrm{MgCl}_{2}, 8 \mathrm{mM} \mathrm{CaCl}_{2}, 1.6 \%$ [v/v] NP-40, 1.3\% [v/v] Triton $\mathrm{X}-100$, and $0.001 \%[\mathrm{v} / \mathrm{v}] \mathrm{DMSO})$. Nuclear pellets were washed once in ice-cold PBS, snap-frozen in liquid nitrogen, and subsequently used for the preparation of nuclear RNA. To obtain nuclear extracts, nuclei were resuspended in immunoprecipitation (IP) buffer (45 mM HEPES/ $\mathrm{NaOH}$ at $\mathrm{pH} 7.5,0.45 \mathrm{M} \mathrm{NaCl}$, $0.9 \mathrm{mM}$ EDTA, $0.9 \%$ [v/v] NP-40, 8.7\% [v/v] glycerol, $1 \mathrm{mM} \mathrm{NaF}$, $10 \mathrm{mM} \beta$-glycerophosphate, 1 tablet/50 $\mathrm{mL}$ protease inhibitor cocktail [Roche, no. 1836145]) and sonicated. After centrifugation, the supernatant was snap-frozen in liquid nitrogen and subsequently used for RNA extraction and Northern blot analysis.

\section{In vitro processing assays}

For in vitro processing assays, DNA templates encoding the sequences of various miRNAs were transcribed by T7 polymerase (MEGAshortscript T7, Ambion) in the presence of ${ }^{32} \mathrm{P}-\alpha-\mathrm{UTP}$ (Amersham), thus generating radiolabeled, synthetic precursor miRNAs. The DNA templates were annealed to a T7 runoff DNA oligonucleotide (AATTTAATACGACTCACTATAGG) that spans the T7 promoter site. The sequences used were as follows: premiR-19a, 5'-TCAGTTTTGCATAGATTTGCACAACTACATTCT TCTTGTAGTGCAACTATGCAAAACCTATAGTGAGTCGTATT AA-3'; pre-miR-138-2, 5'-AACCCTGGTGTCGTGAAATAGCC GGGTAAGAGGATGCGCTGCTCGTCGGCCTGATTCACAACA CCAGCCTATAGTGAGTCGTATTAA-3'. These synthetic precursors were folded into their hairpin-shaped structure by heating for $1 \mathrm{~min}$ at $95^{\circ} \mathrm{C}$ and cooling slowly to room temperature. Processing with recombinant Dicer was performed as previously described (Zhang et al. 2002). Precursors were used at a concentration of $10 \mathrm{nM}$ and were pretreated for $10 \mathrm{~min}$ at $30^{\circ} \mathrm{C}$ with increasing amounts of HeLa cytoplasmic extract $(2,4,6,8,16,24$, and $32 \mu \mathrm{g}$ protein for pre-miR-138-2; $2,6,16$, and $32 \mu \mathrm{g}$ protein for pre-miR-19a). After 2 min incubation at $37^{\circ} \mathrm{C}$, the reaction products were separated on a $15 \%$ denaturing PAGE and visualized by autoradiography.

\section{In situ hybridizations}

All mice were maintained at the animal facility at the IMP, under pathogen-free conditions. C57BL/6 mice were mated to generate embryos for analyses and the morning of the vaginal plug was considered as E0.5. Embryos, livers, and brains were post-fixed 
in $4 \%$ paraformaldehyde, cryoprotected (30\% sucrose in PBS), embedded in Tissue-Tek OCT compound, and cryosectioned. Ten-micron cryosections were pretreated, hybridized with LNA digoxygenin-labeled probes (Exiqon), and washed according to Schaeren-Wiemers and Gerfin-Moser (1993), with some modifications. Probe sequences were as follows: miR-122a, 5'-ACAAAC ACCATTGTCACACTCCA-3'; miR-138, 5'-CGGCCTGATTCA CAACACCAGCT-3'; and pre-miR-138-2, 5'-GGTAAGAGGATG CGCTGCTCGT- $3^{\prime}$. Briefly, sections were fixed in $4 \%$ paraformaldehyde for $10 \mathrm{~min}$, acetylated, and treated with $5 \mu \mathrm{g} / \mathrm{mL}$ proteinase $\mathrm{K}$ (Roche) in PBS for $5 \mathrm{~min}$, washed, and prehybridized for $4 \mathrm{~h}$ at room temperature. Hybridization with 22-nt LNA probes $\left(T_{m} \sim 80^{\circ} \mathrm{C}\right)$ was performed at $55^{\circ} \mathrm{C}$ overnight. Slides were then washed at $60^{\circ} \mathrm{C}$ and incubated with alkaline phophataseconjugated goat anti-DIG Fab fragments (1:2000 [Roche]) at $4^{\circ} \mathrm{C}$ overnight. Fluorescent detection was performed using a Fast Red reaction (Dako Cytomation) for $1 \mathrm{~h}$ at room temperature. Sections were analyzed with a with a Zeiss Axioplan-2 microscope and photographed with a digital camera (Coolsnap HQ, Photometrics). A subset of images was adjusted for levels, brightness, contrast, hue, and saturation with Adobe Acrobat 7.0 imaging software to optimally visualize the expression patterns.

\section{SUPPLEMENTAL MATERIAL}

Supplemental Material can be found at http://www.imba.oeaw. ac.at/index.php?id=142.

\section{ACKNOWLEDGMENTS}

We thank Stefan Ameres, Stefan Weitzer, and the members of the laboratory for encouragement and suggestions during the completion of this work, and Prof. Renée Schroeder for critically reading the manuscript. J.M. is a Junior Group Leader at IMBA. P.J.F.L. is funded by the Boehringer Ingelheim Fonds Ph.D. Scholarship. M.A. was supported by an EMBO long-term fellowship and a Marie Curie fellowship.

Received December 12, 2005; accepted April 24, 2006.

\section{REFERENCES}

Ambros, V., Lee, R.C., Lavanway, A., Williams, P.T., and Jewell, D. 2003. MicroRNAs and other tiny endogenous RNAs in C. elegans. Curr. Biol. 13: 807-818.

Babak, T., Zhang, W., Morris, Q., Blencowe, B.J., and Hughes, T.R. 2004. Probing microRNAs with microarrays: Tissue specificity and functional inference. RNA 10: 1813-1819.

Barad, O., Meiri, E., Avniel, A., Aharonov, R., Barzilai, A., Bentwich, I., Einav, U., Gilad, S., Hurban, P., Karov, Y., et al. 2004. MicroRNA expression detected by oligonucleotide microarrays: System establishment and expression profiling in human tissues. Genome Res. 14: 2486-2494.

Bartel, D.P. 2004. MicroRNAs: Genomics, biogenesis, mechanism, and function. Cell 116: 281-297.

Bentwich, I., Avniel, A., Karov, Y., Aharonov, R., Gilad, S., Barad, O., Barzilai, A., Einat, P., Einav, U., Meiri, E., et al. 2005. Identification of hundreds of conserved and nonconserved human microRNAs. Nat. Genet. 37: 766-770.

Berezikov, E., Guryev, V., van de Belt, J., Wienholds, E., Plasterk, R.H., and Cuppen, E. 2005. Phylogenetic shadowing and computational identification of human microRNA genes. Cell 120: $21-24$

Bernstein, E., Caudy, A.A., Hammond, S.M., and Hannon, G.J. 2001. Role for a bidentate ribonuclease in the initiation step of RNA interference. Nature 409: 363-366.

Bohnsack, M.T., Czaplinski, K., and Gorlich, D. 2004. Exportin 5 is a RanGTP-dependent dsRNA-binding protein that mediates nuclear export of pre-miRNAs. RNA 10: 185-191.

Calin, G.A., Liu, C.G., Sevignani, C., Ferracin, M., Felli, N., Dumitru, C.D., Shimizu, M., Cimmino, A., Zupo, S., Dono, M., et al. 2004. MicroRNA profiling reveals distinct signatures in B cell chronic lymphocytic leukemias. Proc. Natl. Acad. Sci. 101: 11755-11760.

Griffiths-Jones, S. 2004. The microRNA registry. Nucleic Acids Res. 32: D109-D111.

Hutvágner, G., McLachlan, J., Bálint, É., Tuschl, T., and Zamore, P.D. 2001. A cellular function for the RNA interference enzyme Dicer in small temporal RNA maturation. Science 93: 834-838.

Ketting, R.F., Fischer, S.E., Bernstein, E., Sijen, T., Hannon, G.J., and Plasterk, R.H. 2001. Dicer functions in RNA interference and in synthesis of small RNA involved in developmental timing in C. elegans. Genes \& Dev. 15: 2654-2659.

Khvorova, A., Reynolds, A., and Jayasena, S.D. 2003. Functional siRNAs and miRNAs exhibit strand bias. Cell 115: 209-216.

Knight, S.W. and Bass, B.L. 2001. A role for the RNase III enzyme DCR-1 in RNA interference and germ line development in C. elegans. Science 2: 2.

Lagos-Quintana, M., Rauhut, R., Lendeckel, W., and Tuschl, T. 2001. Identification of novel genes coding for small expressed RNAs. Science 294: 853-858.

Lagos-Quintana, M., Rauhut, R., Yalcin, A., Meyer, J., Lendeckel, W., and Tuschl, T. 2002. Identification of tissue-specific microRNAs from mouse. Curr. Biol. 12: 735-739.

Lee, Y., Ahn, C., Han, J., Choi, H., Kim, J., Yim, J., Lee, J., Provost, P., Radmark, O., Kim, S., et al. 2003. The nuclear RNase III Drosha initiates microRNA processing. Nature 425: 415-419.

Lehnertz, B., Ueda, Y., Derijck, A.A., Braunschweig, U., PerezBurgos, L., Kubicek, S., Chen, T., Li, E., Jenuwein, T., and Peters, A.H. 2003. Suv39h-mediated histone H3 lysine 9 methylation directs DNA methylation to major satellite repeats at pericentric heterochromatin. Curr. Biol. 13: 1192-1200.

Lim, L.P., Glasner, M.E., Yekta, S., Burge, C.B., and Bartel, D.P. 2003. Vertebrate microRNA genes. Science 299: 1540.

Liu, C.G., Calin, G.A., Meloon, B., Gamliel, N., Sevignani, C., Ferracin, M., Dumitru, C.D., Shimizu, M., Zupo, S., Dono, M., et al. 2004. An oligonucleotide microchip for genome-wide microRNA profiling in human and mouse tissues. Proc. Natl. Acad. Sci. 101: 9740-9744.

Lund, E., Guttinger, S., Calado, A., Dahlberg, J.E., and Kutay, U. 2004. Nuclear export of microRNA precursors. Science 303: 95-98.

Miska, E.A., Alvarez-Saavedra, E., Townsend, M., Yoshii, A., Sestan, N., Rakic, P., Constantine-Paton, M., and Horvitz, H.R. 2004. Microarray analysis of microRNA expression in the developing mammalian brain. Genome Biol. 5: R68.

O'Donnell, K.A., Wentzel, E.A., Zeller, K.I., Dang, C.V., and Mendell, J.T. 2005. c-Myc-regulated microRNAs modulate E2F1 expression. Nature 435: 839-843.

Pillai, R.S. 2005. MicroRNA function: Multiple mechanisms for a tiny RNA? RNA 11: 1753-1761.

Rodriguez, A., Griffiths-Jones, S., Ashurst, J.L., and Bradley, A. 2004. Identification of mammalian microRNA host genes and transcription units. Genome Res. 14: 1902-1910.

Schaeren-Wiemers, N. and Gerfin-Moser, A. 1993. A single protocol to detect transcripts of various types and expression levels in neural tissue and cultured cells: In situ hybridization using digoxigenin-labelled cRNA probes. Histochemistry 100: 431-440.

Schwartz, S., Zhang, Z., Frazer, K.A., Smit, A., Riemer, C., Bouck, J., Gibbs, R., Hardison, R., and Miller, W. 2000. PipMaker-A web server for aligning two genomic DNA sequences. Genome Res. 10: 577-586. 
Schwarz, D.S., Hutvagner, G., Du, T., Xu, Z., Aronin, N., and Zamore, P.D. 2003. Asymmetry in the assembly of the RNAi enzyme complex. Cell 115: 199-208.

Sempere, L.F., Freemantle, S., Pitha-Rowe, I., Moss, E., Dmitrovsky, E., and Ambros, V. 2004. Expression profiling of mammalian microRNAs uncovers a subset of brain-expressed microRNAs with possible roles in murine and human neuronal differentiation. Genome Biol. 5: R13.

Valoczi, A., Hornyik, C., Varga, N., Burgyan, J., Kauppinen, S., and Havelda, Z. 2004. Sensitive and specific detection of microRNAs by northern blot analysis using LNA-modified oligonucleotide probes. Nucleic Acids Res. 32: e175.
Weber, M.J. 2005. New human and mouse microRNA genes found by homology search. FEBS J. 272: 59-73.

Yi, R., Qin, Y., Macara, I.G., and Cullen, B.R. 2003. Exportin-5 mediates the nuclear export of pre-microRNAs and short hairpin RNAs. Genes \& Dev. 17: 3011-3016.

Zhang, H., Kolb, F.A., Brondani, V., Billy, E., and Filipowicz, W. 2002. Human Dicer preferentially cleaves dsRNAs at their termini without a requirement for ATP. EMBO J. 21: 58755885.

Zhao, Y., Samal, E., and Srivastava, D. 2005. Serum response factor regulates a muscle-specific microRNA that targets Hand2 during cardiogenesis. Nature 436: 214-220. 

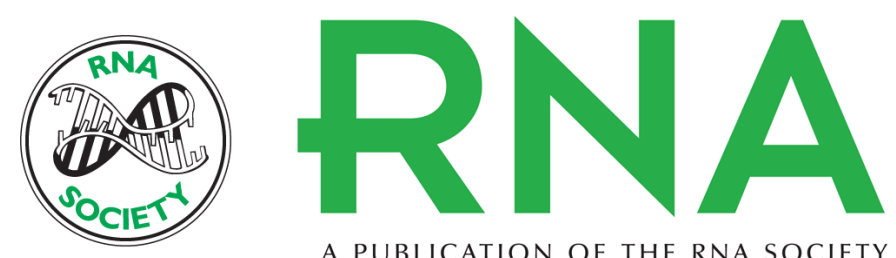

A PUBLICATION OF THE RNA SOCIETY

\section{Post-transcriptional regulation of microRNA expression}

Gregor Obernosterer, Philipp J.F. Leuschner, Mattias Alenius, et al.

RNA 2006 12: 1161-1167

References This article cites 34 articles, 14 of which can be accessed free at: http://rnajournal.cshlp.org/content/12/7/1161.full.html\#ref-list-1

Open Access Freely available online through the RNA Open Access option.

License Freely available online through the open access option.

Email Alerting Receive free email alerts when new articles cite this article - sign up in the box at the Service top right corner of the article or click here.

To subscribe to RNA go to:

http://rnajournal.cshlp.org/subscriptions 